\title{
Establishing Stock Market Attractiveness and Investment Infrastructure in Uzbekistan through Effective Implementation of Corporate Governance Mechanisms
}

Amonboev Mahamasiddiq

Head of the Department, Faculty of Tourism, Tashkent State University of Economics, Uzbekistan

\begin{abstract}
Over the years, large scale of economic reforms has been undertaken in Uzbekistan in order to develop necessary measures to improve investment climate. Compared to GDP, the annual turnover of stock market is 550 times smaller in Uzbekistan and the sale of securities constitutes only $1,6 \%$ of GDP. This shows the low level of market infrastructure development. This article assesses the development potential of the stock market and the scale of development of corporate governance mechanisms in Uzbekistan and provides the application of scientific and theoretical proposals considering economic, political and financial factors. Secondary data sources were used to formulate the paper with the main focus of reviewing best foreign practices.
\end{abstract}

Keywords: Stock market, Corporate governance, Investment climate, Developing economies

\section{Introduction}

\subsection{Stock Market: Concept, Structure and Functions}

The stock market is one of the parts of the financial market, as a commodity on which securities act. Consequently, the concepts of the stock market and the securities market are synonymous. The stock market as a mechanism ensures the redistribution of capital between sectors of the economy. For a better understanding, let's look at a simple example: imagine a company that produces a product that lacks the means to continue production. The company on its own behalf emits (issues) certain securities to the stock market. At the same time, the second company, which owns the in demand sum of money for which, in fact, the papers were issued, buys them. In this way, capital is redistributed between enterprises and industries (Wen, et al, 2015; Liao, 2017). The functions of the securities market are not much different from those of other markets, namely:

-To bring sellers and buyers together to provide a "meeting place" for interested parties.

- To assist with the concentration of free cash, giving investors a wide choice for investment. As a result of this function, some capital on the stock is accumulating.

- The third important function performed by the securities market is the distribution function. Through this function, funds are distributed among different spheres of the economy. In addition, by issuing government bonds, it becomes possible for the governments to eliminate the state budget deficit.

The securities market operates with the help of the following entities:

-Investors - those who buy securities in the stock market for the purpose of investing. 


\section{Amonboev Mahamasiddiq \\ Establishing Stock Market Attractiveness and Investment Infrastructure in Uzbekistan through Effective Implementation of Corporate Governance Mechanisms}

- Professional participants representing the securities market - individuals (both physical and legal) professionally engaged in activities in the securities market (traders, brokers, dealers, etc.).

Conditionally, the securities market can be divided into:

- The primary market is the stock market, to which new securities are issued. The placement can be either an open or a closed type.

- The secondary market exists so that it is possible to trade already issued and purchased securities of the primary market.

Thus, the buyer acquires securities from the producer (issuer) in the primary market, and on the secondary one the buyer acquires them from the intermediary (speculator). The stock market also assumes a number of other criteria for classification: by issuer (public / private companies), by territoriality (international / national / regional market), etc.

\subsection{Largest Stock Exchanges of the World}

According to statistics, the largest stock exchange, representing the securities market is the New York Stock Exchange (NYSE), with a market capitalization of over 16.613 trillion US dollars (World Bank, 2016).

The second most important trading platform, representing the securities market is the US NASDAQ exchange with a capitalization of about 5 trillion US dollars. There are about 3,200 companies in the listing of the stock exchange, 4 of which are Russian. Being a trading system, the NASDAQ exchange provides its indexes of business activity. Each index characterizes the situation in this or that branch of the economy.

The Tokyo Stock Exchange (TSE) is the third largest market capitalization (about 4 trillion US dollars) by the stock exchange. There are 2414 listed companies on the stock exchange market, including the largest Japanese companies such as Honda, Mazda, Toyota, Sony, Nikon and Casio. The main indices of the TSE are NIKKEI 225 and TOPIX (World Stock Exchanges, 2017).

The main stock exchange in Russia is the Moscow Stock Exchange, which was formed after the merger of the MICEX and RTS in 2011. The capitalization of the stock market is 23790 billion Rubles. There are 280 companies in the listing including Russian giants such as Gazprom, Sberbank and Lukoil among them and many others. The leading stock indexes on the Moscow stock exchange are the MICEX index (which is in Rubles) and the RTS index (in US dollars).

\section{Analysis of Uzbek Stock Market}

From the initial years of Independence, Uzbekistan focused on sustainable socio-economic development. In this regard, great attention has been paid to the country's rich resources of raw materials, high-tech industries and business development. Currently, the expansion of investment of the stock companies is conducted through the regulation of corporate governance mechanism principles and it is considered as a priority by the state (Kolev, 2011).

Corporate sector investment is considered as an investment in the securities market to attract the necessary funds. In fact, large-scale development of industrial enterprises in the economy is mainly determined by the extent of stock market development. Stock markets in developing countries provide regular information for stockholders on their investment, and about that markets have most shares in the sector (uzse.uz, 2016). 


\section{Amonboev Mahamasiddi q}

Establishing Stock Market Attractiveness and Investment Infrastructure in Uzbekistan through Effective Implementation of Corporate Governance Mechanisms

Total amount of the Tashkent Republican Stock Exchange in 2016 was recorded as the highest in the history of the activities equal to 299.5 billion Sums and compared to 2015 trade (uzse.uz, 2016). If this figure is compared to the gross domestic products of Uzbekistan, it is still remains as a very small figure. Uzbekistan's gross domestic product in 2016 reached 164932,06 billion soums. Yet, in developing countries, the practice of gross domestic product comparison to the stock market is completely unacceptable, since, turnover ratio of stock market is higher compared to GDP.

The stock market is considered to be in a stage of formation. Recent legislative changes undertaken in Uzbekistan is aimed at improving the regulation of corporations and corporate governance principles and therefore, actions were taken to decrease the state participation in the economy. According to the information provided in global economy, the stock market capitalization of about $50 \%$ of GDP is considered as an indication of improved state participation in economy. Nevertheless, it is also worthy to mention that most countries do not have stock markets.

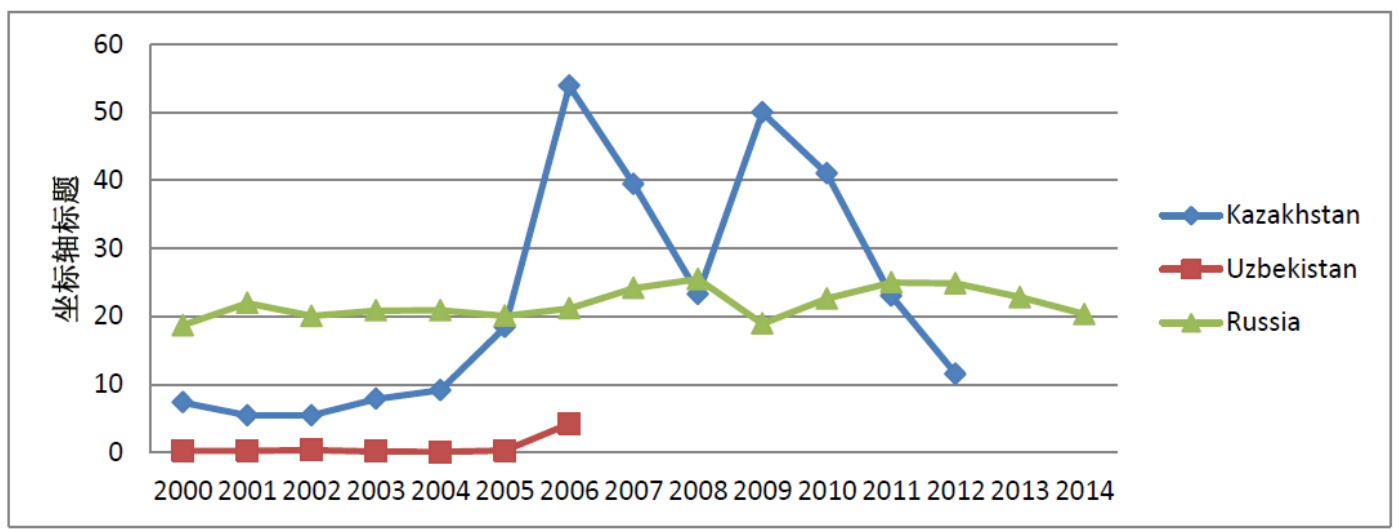

Figure 1: Stock Market trends in Russia, Kazakhstan and Uzbekistan , 2014

Source: globaleconomy.com (2015)

The figure compares the stock market trends in Kazakhstan, Uzbekistan and Russia during the period of 2000-2015. In the case of Uzbekistan, the data is only available till 2006, which shows the stock market capitalization rate of $4 \%$ of GDP. As it is clearly seen, it is quite low compared to that of Russia and Kazakhstan. The figure 2 presents that stock market trend in Kazakhstan follows more fluctuations.

Declining stock market can be the reason for low market capitalization rates during 2000-2006 in Uzbekistan. In this regard, it is important to mention that large market capitalization does not always indicate that stock market is indeed active since stock market can be made up of large companies whose shares are traded regularly. 


\section{Amonboev Mahamasiddi q}

Establishing Stock Market Attractiveness and Investment Infrastructure in Uzbekistan through Effective Implementation of Corporate Governance Mechanisms

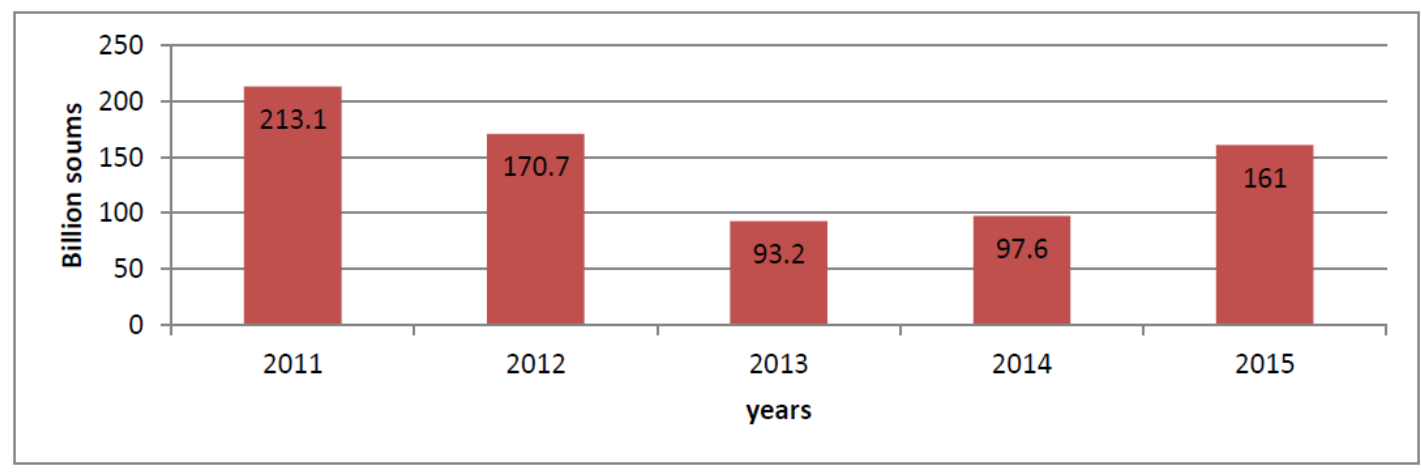

Figure 2: (Stock market capitalization rates, 2011-2015)

Source: Tashkent Stock Exchange

Nevertheless, it is important to note that government measures to develop stock market led to the improvement of stock market trends in Uzbekistan. For example, the total number of deals at the Republican Stock Exchange "Tashkent" accounted for 2794 deals at the end of 2015 which is considered to be three times more compared to the same period of 2014 (Stock Exchange Review, 2015).

- In the secondary market, 205,5 billion soums worth of trade agreements

- An additional issue of shares -68.0 billion soums worth of trade agreements, of which 10.0 billion Soums (US \$ 3.4 million..) are sold in foreign currency;

- Corporate bonds signed an agreement worth 4.0 billion.

The total trade turnover of the economy in 2016 , the financial sector accounted for $51.6 \%$, or 154.6 billion soums. In 2015 , the trade turnover of the financial sector accounted for $88.4 \%$, or 141.3 billion. The share of the total trade turnover of agro-industrial complex increased by $5.3 \%$ or 14.9 billion soums.

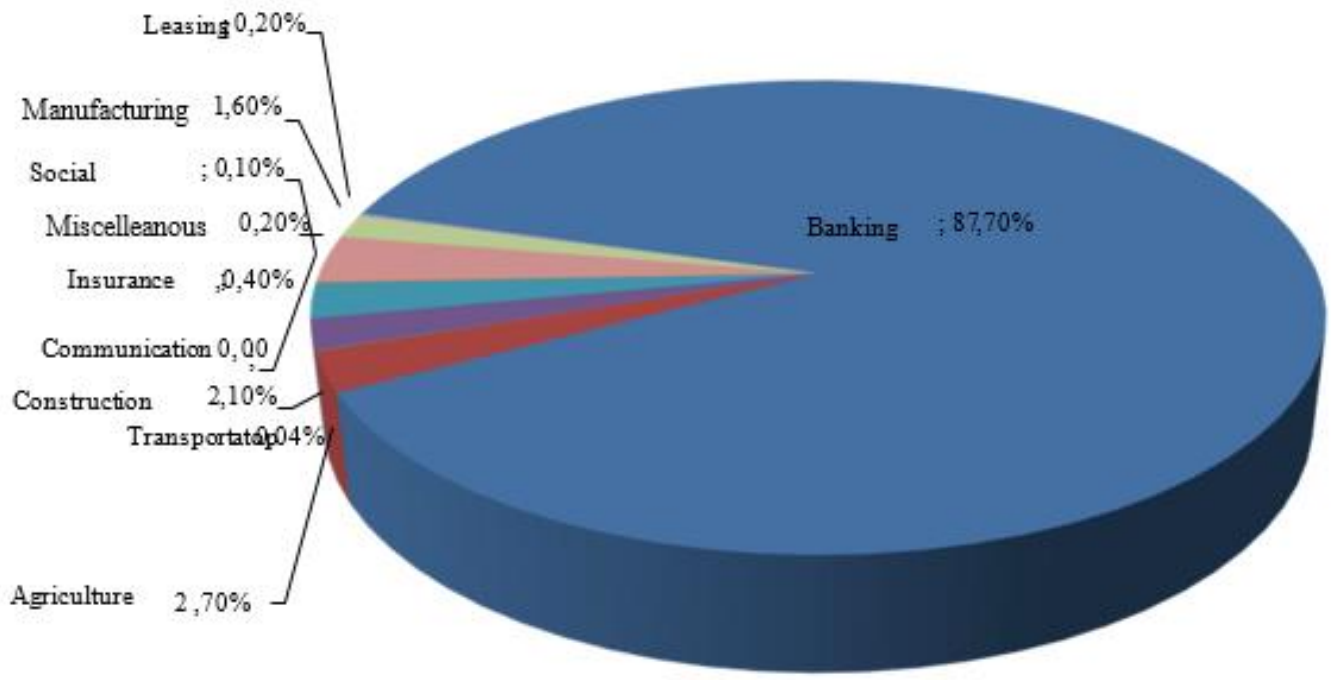

Figure 3: The total turnover of securities trading on the stock market share across all areas Source: xabardor.uz/jahon-fond-bozori-kecha-va-bugun

According to the analysis of investors, the total trade turnover of the stock market in 2016, legal entities made up $83.7 \%$ or 251.2 billion soums of the total volume of transactions (Uzse.uz, 


\section{Amonboev Mahamasiddi q}

Establishing Stock Market Attractiveness and Investment Infrastructure in Uzbekistan through Effective Implementation of Corporate Governance Mechanisms

2016). Furthermore, $50.1 \%$ or 150.2 billion soum worth of shares are from foreign investors. Share of individuals in the total trade turnover increased by $16.2 \%$ or by 48.6 billion soums, of which $3.9 \%$ or 11.7 billion are share of foreign investors. Modernization and innovative development of the economy requires large-scale investments. In this process, the financial markets play an important role in the securities market. The level of development of the securities market plays important role in country's financial market development. In addition, the securities market development and international integration of the national economy is an important factor in helping to attract foreign investment. Therefore, special attention is paid to the development of the securities market in the economic development of all countries.

Table 1: Stock market capitalization

\begin{tabular}{|l|l|l|l|l|l|l|l|l|l|l|l|}
\hline & $\begin{array}{l}\text { Country } \\
\text { Name }\end{array}$ & $\begin{array}{l}200 \\
5\end{array}$ & $\begin{array}{l}200 \\
6\end{array}$ & $\begin{array}{l}200 \\
7\end{array}$ & $\begin{array}{l}200 \\
8\end{array}$ & $\begin{array}{l}200 \\
9\end{array}$ & $\begin{array}{l}201 \\
0\end{array}$ & $\begin{array}{l}201 \\
1\end{array}$ & $\begin{array}{l}201 \\
2\end{array}$ & $\begin{array}{l}201 \\
3\end{array}$ & $\begin{array}{l}201 \\
4\end{array}$ \\
\hline 1 & $\begin{array}{l}\text { United } \\
\text { States }\end{array}$ & $\begin{array}{l}128, \\
39\end{array}$ & $\begin{array}{l}133, \\
39\end{array}$ & $\begin{array}{l}137, \\
36\end{array}$ & $\begin{array}{l}109, \\
70\end{array}$ & $\begin{array}{l}92,9 \\
6\end{array}$ & $\begin{array}{l}108, \\
32\end{array}$ & $\begin{array}{l}107, \\
38\end{array}$ & $\begin{array}{l}106, \\
97\end{array}$ & $\begin{array}{l}128, \\
12\end{array}$ & $\begin{array}{l}146, \\
28\end{array}$ \\
\hline 2 & China & $\begin{array}{l}18,8 \\
2\end{array}$ & $\begin{array}{l}28,5 \\
5\end{array}$ & $\begin{array}{l}80,6 \\
0\end{array}$ & $\begin{array}{l}73,3 \\
0\end{array}$ & $\begin{array}{l}53,1 \\
9\end{array}$ & $\begin{array}{l}66,6 \\
9\end{array}$ & $\begin{array}{l}52,2 \\
0\end{array}$ & $\begin{array}{l}42,5 \\
6\end{array}$ & $\begin{array}{l}40,7 \\
8\end{array}$ & 48,3 \\
2
\end{tabular}




\section{Amonboev Mahamasiddiq}

Establishing Stock Market Attractiveness and Investment Infrastructure in Uzbekistan through Effective Implementation of Corporate Governance Mechanisms

\begin{tabular}{|l|l|l|l|l|l|l|l|l|l|l|l|}
\hline 12 & $\begin{array}{l}\text { Uzbekist } \\
\text { an }\end{array}$ & 0,14 & 2,20 &.. &.. &.. &.. &.. &.. &.. &.. \\
\hline 13 & $\begin{array}{l}\text { Kyrgyz } \\
\text { Republic }\end{array}$ & 1,57 & 2,38 & 2,85 & 2,20 & 1,62 & 1,50 & 2,00 & 2,45 &.. &.. \\
\hline 14 & $\begin{array}{l}\text { Tajikista } \\
\mathrm{n}\end{array}$ &.. &.. &.. &.. &.. &.. &.. &.. &.. &.. \\
\hline
\end{tabular}

Source: databank.worldbank.org/data/reports.aspx?source=statistical-capacity-indicators

Table 2: Stock market total value traded to GDP, \%

\begin{tabular}{|c|c|c|c|c|c|c|c|c|c|c|c|}
\hline & $\begin{array}{l}\text { Country } \\
\text { Name }\end{array}$ & 2005 & 2006 & 2007 & 2008 & 2009 & 2010 & 2011 & 2012 & 2013 & 2014 \\
\hline 1 & $\begin{array}{l}\text { United } \\
\text { States }\end{array}$ & 172,60 & 205,58 & 254,62 & 313,59 & 285,38 & 235,50 & 250,95 & 229,25 & 196,97 & 209,74 \\
\hline 2 & China & 20,03 & 28,61 & 106,73 & 118,55 & 116,64 & 136,73 & 104,90 & 70,36 & 67,59 & 95,39 \\
\hline 3 & Japan & 84,51 & 110,49 & 137,56 & 142,24 & 106,14 & 76,53 & 76,42 & 64,51 & 89,31 & 114,42 \\
\hline 4 & $\begin{array}{l}\text { German } \\
\mathrm{y}\end{array}$ & 43,03 & 53,97 & 77,90 & 102,55 & 84,16 & 46,71 & 41,88 & 38,30 & 34,74 & 33,37 \\
\hline 5 & $\begin{array}{l}\text { United } \\
\text { Kingdom }\end{array}$ & 68,98 & 86,79 & 116,46 & 114,83 & 110,39 & 124,40 & 123,22 & 103,67 & 76,02 & 68,98 \\
\hline 6 & India & 51,67 & 57,96 & 75,48 & 79,65 & 72,23 & 64,68 & 45,95 & 32,59 & 29,73 & 30,90 \\
\hline 7 & $\begin{array}{l}\text { Korea, } \\
\text { Rep. }\end{array}$ & 99,90 & 130,66 & 146,86 & 142,00 & 150,44 & 160,45 & 152,32 & 143,17 & 113,81 & 95,13 \\
\hline 8 & $\begin{array}{l}\text { Russian } \\
\text { Federati } \\
\text { on }\end{array}$ & 17,88 & 36,94 & 71,96 & 76,14 & 59,99 & 34,37 & 28,71 & 21,76 & 13,74 & 9,57 \\
\hline 9 & Spain & 79,49 & 98,33 & 131,26 & 128,53 & 96,71 & 89,84 & 86,31 & 70,98 & 65,69 & 68,82 \\
\hline 10 & $\begin{array}{l}\text { Ka za khst } \\
\text { an }\end{array}$ & 1,82 & 2,17 & 5,16 & 4,99 & 3,18 & 1,68 & 0,29 & 0,40 & 0,39 & 0,34 \\
\hline 11 & Ukraine & 0,50 & 0,85 & 1,09 & 1,27 & 1,03 & 2,01 & 1,26 & 0,51 & 0,26 & 0,14 \\
\hline 12 & $\begin{array}{l}\text { Uzbekist } \\
\text { an }\end{array}$ & 0,15 & 0,17 & 0,25 & 0,31 & 0,13 & 0,06 & 0,13 & .. & .. & .. \\
\hline 13 & $\begin{array}{l}\text { Kyrgyz } \\
\text { Republic }\end{array}$ & 1,70 & 1,97 & 3,18 & 2,58 & 1,74 & 0,79 & 0,10 & 0,06 & .. & .. \\
\hline
\end{tabular}




\begin{tabular}{|l|l|l|l|l|l|l|l|l|l|l|l|}
\hline 14 & $\begin{array}{l}\text { Tajikista } \\
\mathrm{n}\end{array}$ &.. &.. &.. &.. &.. &.. &.. &.. &.. &.. \\
\hline
\end{tabular}

Source: databank.worldbank.org/data/reports.aspx?source=statistical-capacity-indicators

This table shows the geographical location, the level of development of the stock markets and the size of the gross domestic product and their changes in the stock market of different countries. Table 1 below shows, the stock market in developed countries, a high proportion of the gross domestic products, in particular the United States in 2014 at $146 \%, 132 \%$ in the UK in 2012. Due to the world financial and economic crisis observed in 2007, we can see the drop in the stock market capitalization in Russia, China, Spain and Japan. The condition in Kazakhstan, Ukraine, and Uzbekistan is close to each other, which resulted in unfavourable climate for the capitalization of the stock market. The US has also become a leader in some years, the volume of trading in the stock market. US are followed by Japan, South Korea, and England. Some of the countries have also observed a fall in 2007. In this regard, the figures corresponding to Uzbekistan shows that stock market is not functioning properly.

Considering the case of developed economies, several scientists Avci, (2010); Polk (2009); Hong (2007) argue that stock market practices of developed countries may not fit the context of developing countries. Some researchers Singh (2013); Wen (2015); Kalev (2015)claim that such practices may impede economic growth instead of fostering it towards the growth. For instance, Singh (2013) mentioned that several important elements of mature markets such as volatility, deterrence of risk-averse savers, speculative nature of investors may not only have negative influence on the development of stock markets but also may have adverse impact on the economic growth of that country. Several researchers including Yartey (2009) provide support for the findings of the Singh. Yartey (2009) studied the correlation between stock market and economic grow th using the case of 14 African countries based on the three indicators of stock market development. These indicators include market capitalization relative to GDP, turnover ratio and value of shares traded to GDP. The findings of the study show that total value of shares are found to have positive on growth of market capitalization.

Moreover, the case of developed countries such as USA shows that stock markets may not be relevant option for financing country's industrial expansion, which crea tes another argument on the viability of stock market and economic growth link (Mohammad, 2015; Fang, 2009). For example, statistics show that the industrialization level of US market has already reached maturity level when stock market has just begun functioning. Furthermore, US governmental subsidies financed the current state of railroad systems and retained earnings and debts were used to finance the major US oil companies. Thus, many US corporations are believed to be financed without relying largely on public equity financing (Mitchell, 2013). In this regard, Mitchell (2013) argues that stock markets are more likely to distort production incentives instead of fostering them which will have negative impact on economic growth. Furthermore, Singh (2013) mentioned that Asian giant countries including Japan, Korea and Taiwan did not benefit from the stock market operations even after war industrialization period. These findings are more likely to lessen the potential impact that stock market may have to improve the economic growth.

\subsection{Issues Faced by Stock Market in Uzbekistan}

It is important to ensure the transparency of sales of shares according to the principles of corporate governance. In particular, market conditions for each participant must ensure that the stock market offers necessary mechanism for each participant. Several reasons are given to explain this condition (Uzse.uz, 2016)

- The lack of trust of the population and businesses to shares in the country; 


\section{Amonboev Mahamasiddiq}

Establishing Stock Market Attractiveness and Investment Infrastructure in Uzbekistan through Effective Implementation of Corporate Governance Mechanisms

- Decline in the industry initiatives to attract investment through the stock market;

- Absence of practical measures taken by government to develop stock market system;

- The lack of media coverage of stock market practices;

- The main principles of corporate governance are not followed;

- There is no enough information provided about investment climate for investors.

\subsection{Foreign Experience of Investment Attraction}

The review of the latest strategy of Uzbekistan shows that support for the development of stock exchange is provided for foreign investors through privatization program. For instance, according to the presidential decree on March 19, 2012, Korea exchange is expected to become a shareholder of Tashkent Stock Exchange in 2014 by acquiring $25 \%$ of equity capital. Generally, the largest shareholders of Tashkent Stock Exchange are found to be largest commercial banks and state. In this regard, it is critical to study the advanced stock market system such as that of South Korea. South Korea focuses on increasing the role of stock exchanges through foreign investments as one of the fastest growing economies,

According to the statistics provided at the end of 2011, foreign ownership of domestic exchangelisted shares made up KRW 351.5 trillion. The domestic stock market became first available for foreign investors in 1992. As it can be seen, the percentage of domestic shares owned by foreign investors increases steadily by reaching a peak of $42,1 \%$ in July of 2004 . However, starting from 2005 this indicator began to decrease owing to the upcoming financial crisis and rallies of equities in emerging markets (Kofia.or.kr).

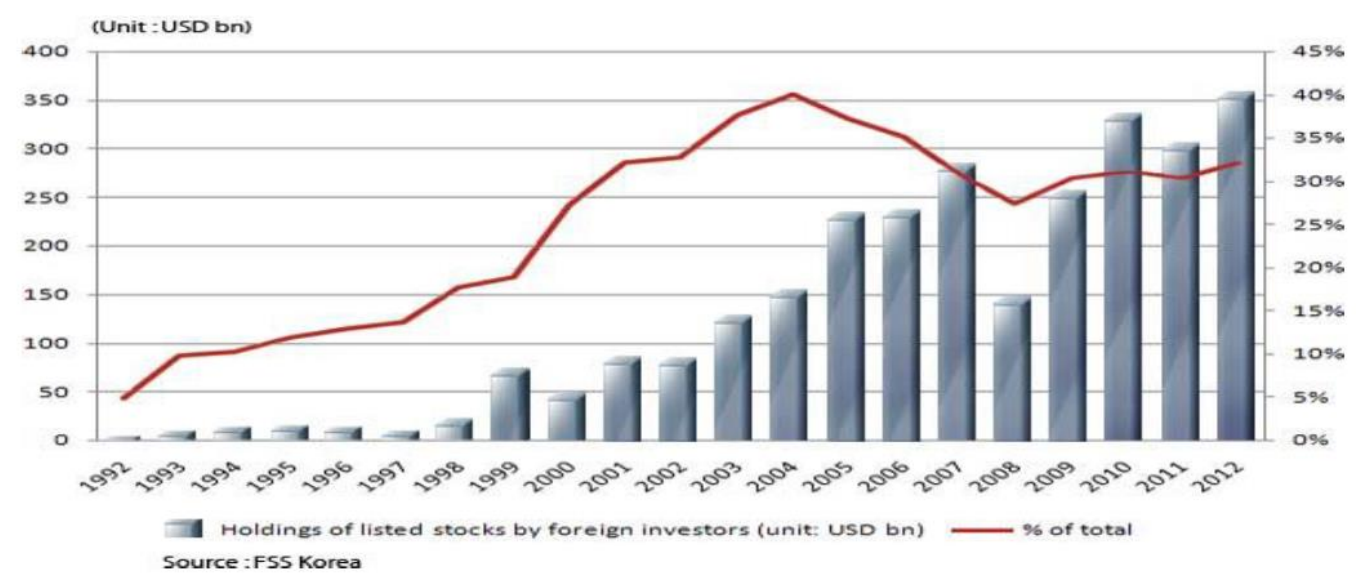

Figure 5: (Holdings of listed stocks by foreign investors, source: FSS Korea, 2012)

The case of Russian Stock market shows that starting from 2013 Russian stock market indicators began to decrease due to the decreasing oil prices and western sanctions. In response, Russian government attempted to recover the stock market loss by attracting more foreign investors (World Bank, 2016). This was undertaken through the change of dividend policy of country's leading state corporations as well as implementation of other regular measures (Jain, 2013, Elein, 2015). According to the analysts, majority of foreign investors returned to the Russian stock market.

According to analysts, so far, the majority of foreign investors, which suspended their activities in Russia due to the crisis, have decided to return to the market. The ever growing interest is observed in the case of a wide range of foreign investors from hedge funds to large investment funds. Overall, the biggest activities of foreigners in the Russian market are currently observed in the segments of corporate bonds, as well as government bonds and equities (Fang, 2009). 


\section{Recommendations and Conclusion}

No single information is received from stock market about possible deals which can be evidence of the fact that the stock market operations are not transparent. If the above mentioned problems are not solved on time based on market economy principles, the development of stock market based on corporate governance principles will be under question. The solution to these problems can be provided based on the corporate governance principles. In order to ensure the effective operation of corporate governance, it is important to regulate the all of its mechanisms including economic, motivational, organizational and financial mechanisms. Moreover, solution for the current problems can be achieved by tailoring specific objectives of the corporate governance principles.

In this regard, economical mechanism requires taking the following actions based on authors own observations:

Every investment project should clearly outline what percentage of funds will be issued through stock market. To determine a minority, share of economic interests. Political mechanism requires the following actions:

Part of the shares should be sold to business entities on the basis of stock market laws to increase the share of minority shareholders in addition to the introduction of preferences.

Financial mechanism:

- -Provide reports on certain forms of permanent books of account:

- -Provide net income forecasts of Investment projects

- -Establish ongoing media coverage of stock market situation and is participants

- Offer information about net incomes through websites

Legal mechanism:

Interests of each participant should be supported based on legislative framework. Investments and further expansion of these mechanisms plays an important role in developing of the stock market. Precisely, following the above mentioned mechanisms of corporate governance is known to be critically important for the development of stock market in Uzbekistan.

\section{References}

- Accounting, Vol. 23 Issue: 1, pp.39-67

- Adjasi, C.K. and Biekpe, N.B., 2006. Stock market development and economic growth: The case of selected African countries. African Development Review, 18(1), pp.144-161. Crossref

- Asker, J., Farre-Mensa, J. and Ljungqvist, A., 2015. Corporate investment and stock market listing: A puzzle?. The Review of Financial Studies, 28(2), pp.342-390. Crossref

- Bollen, J., Mao, H. and Zeng, X., 2011. Twitter mood predicts the stock market. Journal of computational science, 2(1), pp.1-8. Crossref

- Boyacioglu, M.A. and Avci, D., 2010. An adaptive network-based fuzzy inference system (ANFIS) for the prediction of stock market return: the case of the Istanbul stock exchange. Expert Systems with Applications, 37(12), pp.7908-7912. Crossref

- Brock, W., Lakonishok, J. and LeBaron, B., 2015. Simple technical trading rules and the stochastic properties of stock returns. The Journal of finance, 47(5), pp.1731-1764. Crossref

- Fang, V.W., Noe, T.H. and Tice, S., 2009. Stock market liquidity and firm value. Journal of financial Economics, 94(1), pp.150-169. Crossref

- Hameed, A., Kang, W. and Viswanathan, S., 2010. Stock market declines and liquidity. The Journal of Finance, 65(1), pp.257-293. Crossref 


\section{Amonboev Mahamasiddiq}

Establishing Stock Market Attractiveness and Investment Infrastructure in Uzbekistan through Effective Implementation of Corporate Governance Mechanisms

- Hamid, K., Suleman, M.T., Ali Shah, S.Z., Akash, I. and Shahid, R., 2017. Testing the weak form of efficient market hypothesis: Empirical evidence from Asia-Pacific markets.

- Hong, H. and Stein, J.C., 2007. Disagreement and the stock market. The Journal of Economic Perspectives, 21(2), pp.109-128. Crossref

- Kolev, T. Tanayama and R. Wagenvoort. Investment and Investment Finance in Europe. Economics Department of European Investment Bank. 2013. Published by the European Investment Bank.

- Mohammad Al Mutairi, Gary Tian, Helen Hasan, Andrew Tan, (2012) "Corporate governance and corporate finance practices in a Kuwait Stock Exchange market listed firm: a survey to confront theory with practice", Corporate Governance: The international journal of business in society, Vol. 12 Issue: 5, pp.595-615 Crossref

- Polk, C. and Sapienza, P., 2009. The stock market and corporate investment: A test of catering theory. Review of Financial Studies, 22(1), pp.187-217 Crossref

- quality of forward-looking information: Evidence from the Chinese stock market", Asian Review of

- Roll, R.,(2016). Industrial structure and the comparative behavior of international stock market indices. The Journal of Finance, 47(1), pp.3-41. Crossref

- Thorbecke,W.,(2015) On stock market returns and monetary policy. The Journal of Fina nce, 52(2), pp.635-654. Crossref

- Travlos, N.G., Trigeorgis, L. and Vafeas, N., 2015. Shareholder wealth effects of dividend policy changes in an emerging stock market: The case of Cyprus.

- Wen Qu, Mong Shan Ee, Li Liu, Victoria Wise, Peter Carey, (2015) "Corporate governance and

- Whitelaw, R.F., 2000. Stock market risk and return: An equilibrium approach. Review of Financial Studies, 13(3), pp.521-547.

- World Bank Doing Business Index Report, 2016. www.doingbusiness.org

- Worldbank (2016) [online] Available http://databank.worldbank.org/data/reports.aspx?source=statistical-capacityindicators $>$ [Accessed June 10, 2017)

- Worldbank (2016) [online] Available from<http://databank.worldbank.org/data/reports.aspx? source=statistical-ca pacityindicators [Accessed June 10, 2017]

- Xabardor.uz (2016) [online] Available from<http://xabardor.uz/jahon-fond-bozori-kechava-bugun $>$ [Accessed June 10, 2017]

- Xiaofeng Shi, Michael Dempsey, Huu Nhan Duong, Petko S. Kalev, (2015) "Investor protection and market liquidity revisited", Corporate Governance, Vol. 15 Issue: 4, pp.517529 Crossref

- Хамидулин М.Б. Развитие финансового механизма корпоративного управления.: монография- Т.:Молия, 2008. 204 с. 